\title{
Nutritional and Sensory Characteristics of Star Fruit and Sweet Orange Juices Blend Fruit Cordial
}

\author{
J. Kesavanath, K. Premakumar and Y. Inthujaa \\ Department of Agricultural Chemistry, Faculty of Agriculture, Eastern University, Sri Lanka
}

\begin{abstract}
Star fruit is one of the tropical fruit that has received less attention from the food industry. A large number of ripened star fruits are wasted during the fruiting-season. Therefore, a study was conducted to develop mixed cordial from star fruit and sweet orange. Star fruit juice, in the amounts of 80,70 and $60 \mathrm{ml}$ were mixed with sweet orange juice for the formulation of $100 \mathrm{ml}$ of cordial. The cordials were subjected to nutritional, microbial and sensory analysis after formulation and during storage. The nutritional analysis of the developed cordials revealed that, titrable acidity, ascorbic acid and total sugar increased with an increase in the level of sweet orange juice, with the 30\% sweet orange juice level, having the values of $0.42 \%, 23.72$ $\mathrm{mg} / 100 \mathrm{ml}$, and $10.34 \%$ respectively and $\mathrm{pH} 3.46$. Sensory analysis showed significant difference between treatments. The cordials were subjected to storage studies at $30^{\circ} \mathrm{C}$ and $\mathrm{RH}$ of $80 \%$ for 11 weeks. The storage studies revealed that, the declining trends in ascorbic acid, $\mathrm{pH}$ and total sugar and increasing trend in titrable acidity. After 11 weeks storage, the mixed cordial of $70 \%$ star fruit juice with $30 \%$ sweet orange juice contained $0.95 \%$ titrable acidity (as citric acid), $16.8 \mathrm{mg} / 100 \mathrm{~g}$ ascorbic acid, $7.2 \%$ total sugar and 3.1 pH. No harmful total plate count was observed in cordials after formulation and during storage. No remarkable changes in sensory characters were observed during storage period. Based on the results of the assessment, the mixed cordial of 70\% star fruit juice with 30\% sweet orange juice was selected as best mixed cordial.
\end{abstract}

KEYWORDS: Cordial, star fruit juice, storage, sweet orange juice 


\section{INTRODUCTION}

The star fruit of carambola (Averrhoa carambola L.) is an attractive fruit of family Oxalidaceae, also known as 'Golden Star'. The fruit, which is mostly consumed fresh or as juice, is rich in vitamins $\mathrm{A}$ and $\mathrm{C}$ along with iron and fiber. The ripe fruit may be processed into fermented or unfermented drinks, jam and jelly etc. In some Asian countries, the green mature fruit is relished and consumed fresh and used in pickle preparations (Avinash et al., 2010). This fruit is not only sold as the fresh fruit of high economic value, but it is also processed as fresh star fruit juice and beverages as ready to serve juice (RTS), cordial and squash.

The sweet orange (Citrus sinensis L. Osbeck.) belongs to citrus fruits. The sweet orange fruit is processed commercially in to various forms mainly juice, frozen concentrates, squash, RTS drinks, nectar, dry mixes, canned segments, juice blends, marmalades and other value added products like pectin and essential oil from peel, natural colors, candied peel, feed yeast etc.

Juice blending is one of the best methods to improve the nutritional quality of the juice. It can improve the vitamin and mineral content depending on the kind and quality of fruits and vegetables used (De Carvalho et al., 2007). Therefore, the study was conducted to find out the most suitable combination of sweet orange star blend fruit cordial and to assess the nutritional and sensory qualities and of sweet orange blend with star fruit cordial after formulation and during storage.

\section{MATERIALS AND METHODS}

\subsection{Preliminary Study}

A preliminary test was carried out to determine initial total soluble solid percentage (TSS \%) and acidity of the fruit juice. The TSS was measured using the hand held refractrometer (ATAGO-S-28E model). Acidity (as \% of anhydrous citric acid) was measured according to the method described in (AOAC, 2002). Mixed cordials were prepared with TSS of $25^{\circ}$ Brix, acidity of $0.30 \%$ and $70 \mathrm{ppm}$ of SMS. Sweet orange blend star fruit cordial was prepared considering the standard limit specified by the Sri Lankan Standards Institute (SLS 214 \& 729: 1985).

According to the calculation, the required amount of star fruit juice, sugar, citric acid and distilled water were weighed. The measured sugar and citric acid were dissolved in water and heated for 5 minutes in the gas cooker to make syrup. The syrup was filtered through the muslin cloth. Thereafter, the star fruit juice added and heated at $85^{\circ} \mathrm{C}$ for $15-20$ minutes. Then the mixture was allowed to cool for 10 minutes. Sodium metabisulphite was added as a preservative. Hot filling was done into already sterilized glass bottles and capped with crown cork immediately. The sealed bottles were put in the hot water bath at $80^{\circ} \mathrm{C}$ for 30 minutes. Then the bottles were allowed to cool.

\subsection{Treatment combination of Star Fruit and Sweet Orange Juices Blend Fruit Cordial}

$\mathrm{T}_{1}$ - Star fruit juice $80 \%+$ sweet orange juice $20 \%$

$\mathrm{T}_{2}$ - Star fruit juice $70 \%+$ sweet orange juice $30 \%$

$\mathrm{T}_{3}-$ Star fruit juice $60 \%+$ sweet orange juice $40 \%$

\subsection{Nutritional, Microbial and Sensory Studies}

Titrable acidity, ascorbic acid, $\mathrm{pH}$ and total sugar were determined for the mixed cordial, according to the standard (AOAC, 2002). Three replicates were used for each treatment. The microbial assessment was carried out by estimating total plate count according to the method by (Maturin and Peeler, 1998). Sensory attributes of colour, aroma, taste, consistency, 
absence of off-flavour and overall acceptability were evaluated by panelists. The seven-point Hedonic scale was used to evaluate the degree of liking (7) and disliking (1) for preference. Three treatments of mixed cordials were stored at ambient temperature $\left(30^{\circ} \mathrm{C}\right)$ in a laboratory for 11 weeks and quality assessment was carried out.

\subsection{Statistical Analysis}

The experiment was done using Complete Randomized Design (CRD). Nutritional studies were analyzed by Analysis of Variance (ANOVA) and the difference between means was compared using Duncan's Multiple Range Test (DMRT), through Statistical Analysis System (SAS) software and the sensory parameters were analyzed by using Tukey Test through SAS Software.

\section{RESULTS AND DISCUSSION}

\subsection{Nutritional characteristics of Fresh Star Fruit and Sweet Orange Juices Blend Fruit Cordial}

A preliminary test was conducted to assess the nutritional and sensory qualities of star fruit and sweet orange juices blend fruit cordial and results are given in the Table 1.

Table 1. Nutritional Characteristic of Fresh Star Fruit and Sweet Orange Juices Blend Fruit Cordial

\begin{tabular}{|l|c|c|c|}
\hline \multirow{2}{*}{ Nutrients } & \multicolumn{3}{|c|}{ Treatments } \\
\cline { 2 - 4 } & $\mathbf{T}_{\mathbf{1}}$ & $\mathbf{T}_{\mathbf{2}}$ & $\mathbf{T}_{\mathbf{3}}$ \\
\hline $\begin{array}{l}\text { Tritrable } \\
\text { acidity(\%) }\end{array}$ & $0.35 \pm 0.01^{\mathrm{b}}$ & $0.42 \pm 0.01^{\mathrm{a}}$ & $0.44 \pm 0.02^{\mathrm{a}}$ \\
\hline $\begin{array}{l}\text { Ascorbic } \\
\text { acid } \\
(\mathbf{m g} / \mathbf{1 0 0 m l})\end{array}$ & $22.44 \pm 1.23^{\mathrm{a}}$ & $23.72 \pm 0.64^{\mathrm{a}}$ & $25.64 \pm 1.05^{\mathrm{a}}$ \\
\hline pH & $3.48 \pm 0.002^{\mathrm{a}}$ & $3.46 \pm 0.002^{\mathrm{b}}$ & $3.45 \pm 0.002^{\mathrm{c}}$ \\
\hline $\begin{array}{l}\text { Total } \\
\text { sugar }(\%)\end{array}$ & $8.08 \pm 0.06^{\mathrm{c}}$ & $10.34 \pm 0.17^{\mathrm{b}}$ & $12.26 \pm 0.36^{\mathrm{a}}$ \\
\hline
\end{tabular}

The values are means of triplicate \pm standard error
Star fruit contained $0.32 \%$, titrable acidity, 10.40 $\mathrm{mg} / 100 \mathrm{ml}$ ascorbic acid, $4.2 \mathrm{pH}$ and $3.25 \%$ total sugar. Whereas sweet orange juice contained $0.48 \%$ titrable acidity, $38 \mathrm{mg} / 100 \mathrm{ml}$ ascorbic acid, $3.5 \mathrm{pH}$ and $8.28 \%$ total sugar. Titrable acidity is directly proportional and is a measure of shelf life of the product and act against the attack of microorganisms (Majumdar et al., 2008). According to the Sri Lanka Standard Institute Specifications, the limit of acidity for cordial preparation is $0.3-1 \%$ as a hydrous citric acid (SLS 214, SLS 221 and SLS 730). The Ascorbic acid level of the star fruit is believed to be responsible for its sugar taste. There were no significant difference between these 3 treatments but ascorbic acid was increased from $22.44 \%$ to $25.64 \%$ with increase the concentration of orange juice from 20 to $40 \%$. $\mathrm{pH}$ of star fruit mixed cordial was significantly $(p<0.05)$ decreased with an increment of sweet orange juice. The total sugar of cordial was significantly $(p<0.05)$ increased with the increment of sweet orange juice concentration.

\subsection{Sensory Evaluation}

The sensory evaluation of mixed fruit cordials revealed that, there was a significant difference between the treatments as the concentration of sweet orange juice was increased from 10 to $30 \%$ at the $5 \%$ significance level. Mean values of treatments according to Tukey's Studentized Range Test are shown in Table 2.

Table 2. Sensory Attributes of Fresh Star Fruit and Sweet Orange Juices Blend Fruit Cordial

\begin{tabular}{|c|c|c|c|c|c|c|}
\hline 参 & $\frac{\grave{z}}{\dot{\theta}}$ & 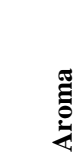 & 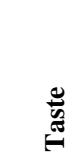 & 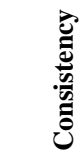 & 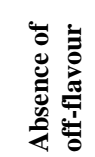 & = \\
\hline $\mathbf{T}_{1}$ & $\begin{array}{l}4.45 \pm \\
0.19^{\mathrm{c}} \\
\end{array}$ & $\begin{array}{l}5.25 \pm \\
0.17^{\mathrm{b}}\end{array}$ & $\begin{array}{l}6.34 \pm \\
0.16^{\mathrm{a}} \\
\end{array}$ & $\begin{array}{l}5.45 \pm \\
0.26^{\mathrm{a}} \\
\end{array}$ & $\begin{array}{l}5.13 \pm \\
0.25^{\mathrm{b}} \\
\end{array}$ & $\begin{array}{l}5.29 \pm \\
0.24^{\mathrm{b}} \\
\end{array}$ \\
\hline $\mathbf{T}_{2}$ & $\begin{array}{l}5.45 \pm \\
0.23^{\mathrm{b}}\end{array}$ & $\begin{array}{l}6.52 \pm \\
0.11^{\mathrm{a}}\end{array}$ & $\begin{array}{l}4.47 \pm \\
0.23^{\mathrm{c}}\end{array}$ & $\begin{array}{l}5.43 \pm \\
0.14^{\mathrm{a}}\end{array}$ & $\begin{array}{l}6.41 \pm \\
0.17^{\mathrm{a}}\end{array}$ & $\begin{array}{l}6.58 \pm \\
0.12^{\mathrm{a}}\end{array}$ \\
\hline $\mathbf{T}_{3}$ & $\begin{array}{l}6.23 \pm \\
0.14^{\mathrm{a}} \\
\end{array}$ & $\begin{array}{l}4.67 \pm \\
0.22^{\mathrm{b}}\end{array}$ & $\begin{array}{l}5.28 \pm \\
0.23^{\mathrm{b}}\end{array}$ & $\begin{array}{l}5.68 \pm \\
0.12^{\mathrm{a}} \\
\end{array}$ & $\begin{array}{l}5.00 \pm \\
0.21^{\mathrm{b}}\end{array}$ & $\begin{array}{l}4.42 \pm \\
0.14^{\mathrm{c}}\end{array}$ \\
\hline
\end{tabular}

The values are means of 30 replicates \pm standard error 
The means with the same letters are not significantly different from each other at 5\% level based on Tukey's Test. Sensory parameters were measured using 7 point hedonic scales

Sensory attributes colour, taste and overall acceptability showed significance difference between the treatments. The overall acceptability of Cordial prepared from $70 \%$ star fruit juice and $30 \%$ sweet orange juice was the highest comparatively to other cordials and the mean value is $6.58 \pm 0.12$. According to the sensory scores all three cordials received high acceptability.

\subsection{Changes in quality Characteristics of Juices Star Fruit and Sweet Orange Blend Fruit Cordial during Storage}

\section{i. Changes Occurrence on Nutritional Qualities of Blend Cordials during Storage}

Three treatments of mixed cordials were stored at ambient temperature $\left(30^{\circ} \mathrm{C}\right)$ in a laboratory for 11 weeks. Changes occurrence on titrable acidity of mixed cordials during storage are shown in Figure 1.

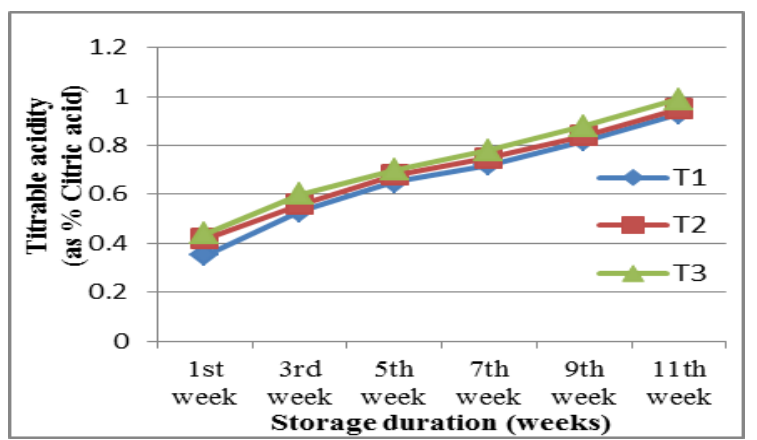

The values are means of triplicates

Figure 1. Changes in Titrable Acidity of Blend Cordial during Storage

The increment of the titrable acidity as shown in Figure 1 is due to the hydrolysis of polysaccharides and oxidation of sugars, which leads to the formation of acids (Fennema, 1996).
This was supported by (Priyanthi et al., 2008) that the acidity value of RTS drink is increased at ambient temperature. The increase in acidity may be ascribed to rise in the concentration of weakly ionized acid and their salts during storage. This increase in acidity might also be due to the formation of acid by degradation of polysaccharides and oxidation of reducing sugars or by the breakdown of pectic substances and uronic acid (Hussain et al., 2008).

Changes occurrence on ascorbic acid content of mixed cordials during storage are shown in Figure 2. The graph clearly indicates that there was a significant difference between the treatments and the period of storage for the ascorbic acid content of mixed cordial at 5\% significance level. This reduction was due to the oxidative degradation of Ascorbic acid to Dehydro-ascorbic acid during storage as the ascorbic acid is highly sensitive to the presence of oxygen in its environment.

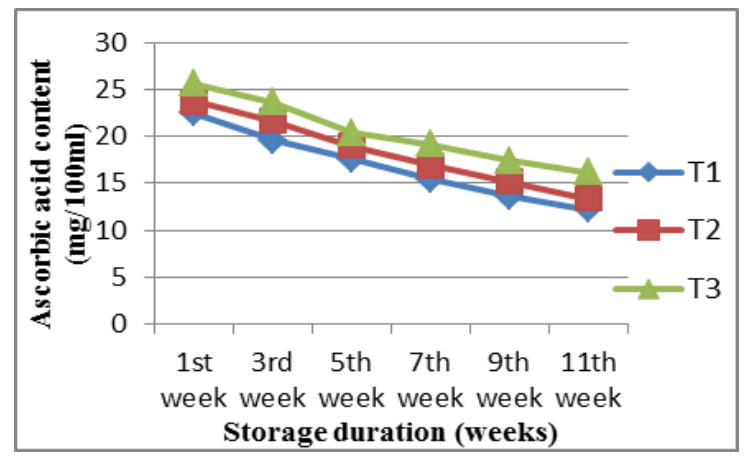

The values are means of triplicates

Figure 2. Changes in Ascorbic acid of Blend Cordials during Storage

Jawaheer et al (2003) also reported that another principal cause of ascorbic acid decrease might be residual oxygen present in the head space of the container (assuming glass ware was impervious to oxygen). The ascorbic acid contents of stored fruit and vegetable products generally decrease at higher storage temperature (Watada et al., 1991).

Changes occurrence on $\mathrm{pH}$ of mixed cordials during storage are shown in Figure 3. High acid 
and low $\mathrm{pH}$ may be due to production of acetic acid and lactic acid during storage at ambient temperature. The least $\mathrm{pH} 3.10$ was reported by in the treatment $\mathrm{T}_{3}$ (Star fruit juice $60 \%+$ sweet orange juice $40 \%$ ). The decrease in $\mathrm{pH}$ was due to increase in titrable acidity which affects the sensory qualities of juice as discussed by (Bhardwaj et al., 2005).

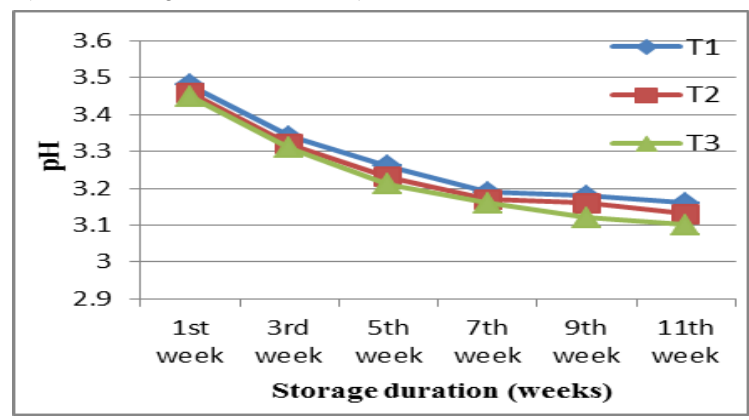

The values are means of triplicates

Figure 3. Changes in $\mathrm{pH}$ of Blend Cordials during Storage

Results pertaining to the total sugar are shown in Figure 4. According to DMRT, total sugar was decreased significantly $(p<0.05)$ throughout the storage period. This could be due to polymerization of sugars at high temperature as discusses by Fennema, 1996. Total sugar in all treatments had the decreasing trend with the storage period because hydrolysis of polysaccharides and oxidation of sugars. Nilugin and Mahendran, (2010) were also found that the significant reduction in total sugar throughout the storage period at ambient temperature in the RTS beverages.

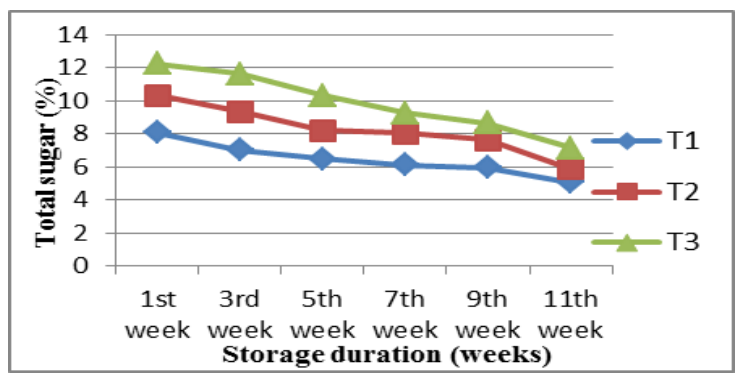

The values are means of triplicates

Figure 4. Changes in Total Sugar of Blend Cordials during Storage ii. Changes Occurrence on Sensory Attributes Star Fruit and Sweet Orange Juices Blend Fruit Cordial during Storage

The changes in sensory attributes are shown in Table 3. Sensory characters of star fruit mixed cordial stored at ambient temperature changed slightly compared to freshly made star fruit mixed cordial during the period of storage. Sensory attributes of star fruit mixed cordial stored at ambient temperature changed slightly compared to freshly made star fruit mixed cordial. This is due to increase in acidity and reduction in total sugar content by oxidative reactions and may be converted to polymer substances (Dhaliwal et al., 2004).

Table 3. Sensory Attributes of Star Fruit and Sweet Orange Juices Blend Fruit Cordial during Storage

\begin{tabular}{|c|c|c|c|c|c|c|}
\hline : & $\frac{\grave{\Xi}}{\dot{\theta}}$ & 竎 & 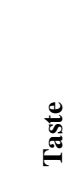 & 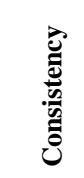 & 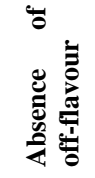 & 苟 \\
\hline $\mathbf{T}_{1}$ & $\begin{array}{l}4.45 \pm \\
0.21^{\mathrm{c}} \\
\end{array}$ & $\begin{array}{l}5.05 \pm \\
0.18^{\mathrm{b}}\end{array}$ & $\begin{array}{l}6.15^{ \pm} \\
0.16^{\mathrm{a}} \\
\end{array}$ & $\begin{array}{l}5.25 \pm \\
0.20^{\mathrm{a}} \\
\end{array}$ & $\begin{array}{l}5.25^{ \pm} \\
0.22^{\mathrm{b}}\end{array}$ & $\begin{array}{l}5.02 \pm \\
0.30^{\mathrm{b}} \\
\end{array}$ \\
\hline $\mathbf{T}_{2}$ & $\begin{array}{l}5.25 \pm \\
0.22^{\mathrm{b}} \\
\end{array}$ & $\begin{array}{l}6.40 \pm \\
0.11^{\mathrm{a}} \\
\end{array}$ & $\begin{array}{l}4.25 \pm \\
0.22^{\mathrm{c}} \\
\end{array}$ & $\begin{array}{l}5.25 \pm \\
0.17^{\mathrm{a}} \\
\end{array}$ & $\begin{array}{l}6.15 \pm \\
0.19^{\mathrm{a}} \\
\end{array}$ & $\begin{array}{l}6.12 \pm \\
0.16^{\mathrm{a}} \\
\end{array}$ \\
\hline $\mathbf{T}_{3}$ & $\begin{array}{l}6.15 \pm \\
0.19^{\mathrm{a}} \\
\end{array}$ & $\begin{array}{l}4.55 \pm \\
0.23^{\mathrm{b}}\end{array}$ & $\begin{array}{l}5.25 \pm \\
0.25^{\mathrm{b}}\end{array}$ & $\begin{array}{l}5.50 \pm \\
0.15^{\mathrm{a}}\end{array}$ & $\begin{array}{l}5.00 \pm \\
0.26^{\mathrm{b}}\end{array}$ & $\begin{array}{l}4.35 \pm \\
0.20^{c} \\
\end{array}$ \\
\hline
\end{tabular}

The values are means of 30 replicates \pm standard error.

The means of treatments showed significance different at 5\% level based on Tukey's Test. Development of off flavours, as a result of oxidation and reduction reactions in food components also slightly affect the sensory attributes of mixed cordial. The mean values of treatments according to Tukey's Test obtained from sensory analysis are shown in Table 3 . The overall acceptability of cordials showed significant difference during storage and the score for the treatments $\mathrm{T}_{1}$ (Star fruit juice $80 \%$ + sweet orange juice 20\%), $\mathrm{T}_{2}$ (Star fruit juice $70 \%+$ sweet orange juice $30 \%$ ), and $\mathrm{T}_{3}$ (Star fruit juice $60 \%+$ sweet orange juice $40 \%$ ) were $5.02,6.12$ and 4.35 respectively. The mixed 
cordial made with $70 \%$ watermelon juice and $30 \%$ sweet orange juice $\left(\mathrm{T}_{2}\right)$ had the highest mean value.

\section{iii. Microbial Test of Star Fruit and Sweet Orange Juices Blend Fruit Cordial Stored at Ambient Temperature}

No bacterial growth was observed in the freshly made mixed cordial. Therefore, there was no total plate count in these samples. Carter et al., 2007 also reported that many products that could safely be maintained sterile by the pasteurization process alone with the addition of sodium metabisulphite. The sulphite inhibits yeasts, moulds and bacteria (Doughari and Elmahmood, 2007).

There were no counts of yeasts and moulds and coli forms in all treatments after the heat treatments and during the storage period. Only the bacterial counts (Total plate counts) were observed after three months of storage. These samples were shown colony forming units (below critical level) in 100 levels which were within the standard limits of total plate count specified by the Sri Lankan Standard Institute (SLS 729:1985) for the RTS fruit beverages.

\section{CONCLUSION}

Finding of the study showed that sweet orange blend star fruit cordials having acceptable quality characteristics. The freshly made mixed cordial with $70 \%$ of star fruit juice with $30 \%$ of sweet orange juice was selected as the best combination among other treatments based on the result of nutritional and sensory analysis. There was no significance difference in the nutritional and sensory qualities of mixed cordial $\mathrm{T}_{2}$ (Star fruit juice $70 \%+$ sweet orange juice $30 \%$ ) after 3 months of storage. Sweet orange blend star fruit cordial made from $70 \%$ star fruit juice and $30 \%$ sweet orange juice was selected as the best combination among other treatments after 3 months of shelf life.

\section{REFERENCES}

AOAC. Official methods of analysis. Association of official analytical chemists. Washington, New York, USA. 2002.

AVINASH GP, DARSHANA AP, ANITA VP $\&$ NARESH C. Physical and chemical characteristics of carambola (Averrhoa carambola 1.) fruit at three stages of maturity. International Journal of Applied Biology and Pharmaceutical Technology. 2010; 1(2): 624 629.

BHARDWAJ JC, JOSHI VK \& LAL KAUSHAL BB. Influence of enzyme, sodium benzoate and yeast immobilization on fermentation of plum must by Schizosaccharomyces Pombe yeast. Acta Horticulturae 696. VII International Symposium on Temperate Zone Fruits in the Tropics and Subtropics Part Two. 2005.

CARTER HW, CHARLEY VL S \& BRISTOL C. The Preservation of fruit Juice Products with special reference to nutritional value. Journal of Cambridge. 2007; 8: $12-14$.

DE CARVALHO JM, GA MAIA RW \& DE FIGUEREDO. Development of a blended nonalcoholic beverage composed of coconut water and cashew apple juice containing caffeine. Journal of Food Quality. 2007; 30: $664-681$.

DHALIWAL M \& HIRA CK. Effect of storage on physico-chemical and nutritional characterstics of Carrot Spinach and CarrotPineapple juices. Journal of Food Science and Technology. 2004; 41: $613-617$.

DOUGHARI JH \& ELMAHMOOD AM. Effect of some chemical Preservatives on the shelf life of sobo drink. African Journal of microbiology. 2007; $2: 5-6$.

FENNEMA OR. Food chemistry. ( $3^{\text {rd }}$ Ed). CRC Press, USA. 1996; $157-412$. 
HUSSAIN S, REHMAN S, RANDHAWA M A \& IQBAL M. Studies on Physico-chemical, microbiological and sensory evaluation of mango pulp storage with chemical preservatives. Journal of Scientometric Research. 2003; 14: 01 -09 .

JAWAHEER B, GOBURDHUN D \& RUGGOO A. Effect of processing and storage of guava into jam and juice on the ascorbic acid content. Plant Food for Human Nutrition. 2003; 58: $1-12$.

MAJUMDAR TK, VASUDISH CR, PREMAVALLI K S \& BAWA AS. Studies on processing and storage stability of ash gourdmint leave juice. Journal of Food Processing and Preservation. 2008; 34: 549 - 556.

MATURIN LJ \& PEELER JT. Aerobic plate count. Chapter. 3. Food and Drug Administration Bacteriological Analytical Manual, $8^{\text {th }}$ Edn. R. L. Merker (Ed.). AOAC International, U.S.A. 1998.

NILUGIN SE \& MAHENDRAN T. Preparation of Ready-To-Serve (RTS) beverage from Palmyrah fruit pulp. Journal of Agricultural Science, Eastern University, Sri Lanka. 2010; 5: $80-88$.

PRIYANTHI H GS, THILAKARATHNE BM $\mathrm{K} \&$ PRASANNA PHP. Development of a ready-to-serve (RTS) drink using Veralu/Ceylon Olive (Elaeocarpusserratus). Abstracts of Final Year Research-2008. Rajarata University, Sri Lanka. 2008; 3: 99.

WATADA AE, AULENBACH BB \& WORTHINGTON JT. Vitamins A and $\mathrm{C}$ in ripe tomatoes as affected by storage of ripeness at harvest and by supplementary ethylene. Journal of Food Science. 1991; 41: 856 - 858. 